\title{
Interpretation of Geological Structures Hosting Potential Gold Deposits in the Konongo Gold Mine Using Airborne Magnetic, Electromagnetic and Radiometric Datasets
}

\author{
Fosu Brempong1, David Dotse Wemegah¹, Kwasi Preko', Thomas Armah ${ }^{2}$, Benjamin Boadi', \\ Aboagye Menyeh ${ }^{1}$, Isaac Amankwah Oppong', Mariam Maku Quarshie ${ }^{1}$, \\ Akwasi Acheampong Aning1, Vandycke Sarpong Asare ${ }^{1}$, Reginald Mensah Noye ${ }^{1}$ \\ ${ }^{1}$ Geophysics Section, Department of Physics, Kwame Nkrumah University of Science and Technology, Kumasi, Ghana \\ ${ }^{2}$ Department of Earth Sciences, University Ghana, Accra, Ghana \\ Email: ddwemegah@gmail.com, obrempongfosu@gmail.com
}

How to cite this paper: Brempong, F., Wemegah, D. D., Preko, K., Armah, T., Boadi, B., Menyeh, A., Oppong, I. A., Quarshie, M. M., Aning, A. A., Asare, V. S., \& Noye, R. M. (2019). Interpretation of Geological Structures Hosting Potential Gold Deposits in the Konongo Gold Mine Using Airborne Magnetic, Electromagnetic and Radiometric Datasets. Journal of Geoscience and Environment Protection, 7, 203-225. https://doi.org/10.4236/gep.2019.76016

Received: April 28, 2019

Accepted: June 27, 2019

Published: June 30, 2019

Copyright () 2019 by author(s) and Scientific Research Publishing Inc. This work is licensed under the Creative Commons Attribution International License (CC BY 4.0).

http://creativecommons.org/licenses/by/4.0/ (c) (7) Open Access

\begin{abstract}
The renewed interest in the reactivation of the defunct National Konongo Gold Mine located in the Ashanti Greenstone Belt, calls for a further probe into its geology and the associated mineral hosting structures to discover its mineralization potential. In order to achieve this, airborne magnetic, radiometric and electromagnetic datasets were interpreted to determine the potential gold hosting features in the studied area. The results show the area to consist of the metasediment, the metavolcanic, Tartwaian Formation and their associated granitoids. Results also show that the Tarkwaian sediments, observed largely in the north-eastern side of the site; widen out substantially and truncate in the south. The analysis of the structure lineaments using a rose diagram reveals three main tectonic structures trending in N-S, NNW-SSE, and third the structure trending in the NNE-SSW to NE-SW directions in the area. The dominant structures in the area, form $90 \%$ of all the delineated structures and trend in the NE-SW and NNE-SSW direction with the remaining $10 \%$ trending in the N-S and NNW-SSE. These structures are associated with the major shear and fracture zones located mainly at the contact between the basin sediments and volcanic belt and also associated with the Tarkwaian Formation. The mapped potential gold mineralization zones located mainly at the contact between the metasediment and the metavolcanic units of the Birimian Supergroup, as well as the Tarkwaian Formation, were mapped by integrating the structures, alteration zones as well as the complex dyke systems. This paper delineates the prominent geological structures with the potential of hosting economic gold mineralization in and around the Ko-
\end{abstract}


nongo Gold Mine.

\section{Keywords}

Radiometry, Magnetic, Electromagnetic, Geological Structures, Gold Mineralization

\section{Introduction}

The Konongo Gold Mine is situated on the western margin of the northeast trending Ashanti Greenstone Belt that contains a substantial amount of world-class hydrothermal gold deposits (Griffis et al., 2002; Perrouty et al., 2012). It is one of the oldest mines in the belt with historic underground mine and several open pits. In terms of geological setting and gold mineralization styles, gold deposits in the area are associated with arsenopyrite-silica-sericite-carbonate alteration as well as deform quartz veins (Oberthür et al., 1994). Historic test work indicates that gold mineralization in Konongo is hosted in disseminated sulphide, quartz veins and weathered metasediment rock (Oberthür et al., 1994). These mineral deposits are structurally controlled and formed during the Eburnean tectono-thermal episode (Griffis et al., 2002). Due to the economic Mineralization potential of Konongo, the concession has been mined in several phases with colonial time mining commencing in 1903. During this period the mine produced approximately 4.4 million tonnes of ore from which about 1.5 to 1.6 million ounces of gold at an average recovery grade of $11.8 \mathrm{~g} / \mathrm{t}$ were obtained (SEMS, 2006; Oliver, 2009; Reidy, 2012). Between 1988 and 1992, a number of shallow open pit mines were operated which yielded 140000 ounces of gold at a grade of $4.7 \mathrm{~g} / \mathrm{t}$ and since then the mine has not been under effective operation. This has been attributed to the difficulty in exploring and discovery of commercial gold deposits on the concession and recently complicated by the upsurge in artisanal mining activities popularly referred to in the local parlance as "Galamsey". The "Galamsey" activity has led to the contamination of soils and river bodies in the area with traces of gold. Hence, the traditional method of exploring for gold through geochemical means becomes marred (Wemegah et al., 2015).

In order not to miss out on the potential economic benefit that commercial gold discovery can bring to the area and the nation as a whole, there is the need to employ exploration methods that are not influenced by the surface trace gold contamination. Furthermore, these methods should have the potential of providing a full understanding of the detailed geological setting, tectonic evolution and its associated geological structures as well as the alteration regime of the area. These are the main controlling features of the Birimian gold mineralization of Ghana. Various researchers have over the years adopted airborne geophysical methods namely magnetic, electromagnetic and radiometric methods in the delineation of potential mineralization zones (Morgan, 2012; Boadi, Wemegah, \& Preko, 2013; Wemegah et al., 2015). The magnetic method uses the difference in 
the magnetic susceptibility of different rocks in mapping the various geological units. This has helped in the mapping of the geological and exploration for mineral deposits particularly in areas with limited outcrops (Jaques et al., 1997; Porwal, Carranza, \& Hale, 2006; Allek \& Hamoudi, 2008; Boadi, Wemegah, \& Preko, 2013; Graham, Wemegah, \& Preko, 2014; Wemegah et al., 2015; Rani et al., 2019). Boadi, Wemegah, \& Preko (2013) interpreted airborne magnetic and radiometric data within the northeastern part of the Ashanti Greenstone Belt to delineate the geology and the associated structures in the area. The results of these works together with authors such as Cozens (1989) and Griffis et al. (2002) show that the Konongo area has the potential of hosting economic gold deposit.

The radiometric method can aid in the mapping of the surface geology due to the different degrees of radioelement distribution in the crustal rocks. This method determines the abundance of potassium, thorium and uranium which are the three main radioelements that can be detected in the top 30 to $50 \mathrm{~cm}$ of the surface rocks (Telford, Geldart, \& Sheriff, 1990; Airo, 2015) based on their gamma-ray responses. Generally, different geological environments including mineralized zones have different composition and distribution of these radioelements. This method, therefore, assists in locating mineral deposits using the differences in the composition of the three radioelements in association with the ore and the hosting rocks (Gunn \& Dentith, 1997; Boadi, Wemegah, \& Preko, 2013; Wemegah et al., 2015). It also determines near surface alteration which is associated with potassium enrichment or depletion in the hosting environment of the deposit (Morgan, 2012; Thomas et al., 2000).

Similarly, high resolution airborne electromagnetic method has the ability to search for small targets and multiple conductors as well as the delineation of zones of alteration. The electromagnetic method is traditionally used in gold and sulphide prospecting for detecting conductive sulphide minerals and shears zones. In case of sulphide minerals (pyrite, arsenopyrite, and chalcopyrite) which are the main pathfinder minerals for gold mineralization in the Birimian formation (Griffis et al., 2002), contrasts in magnetic, resistivity and electromagnetic properties have become direct exploration tools. Generally, the geophysical signatures are produced by zones of gold mineralization is dependent on the ores shape, depth of burial, structure, geological regime, the degree of alteration and the sulphide mineral content.

Wilford, Bierwirth, \& Craig (1997) and Taylor and Eggletion (2001) revealed that the effective way of using geophysical techniques for the discovery of potential mineral target is the adoption of integrated geophysical data which help to resolve ambiguity associated with the geological mapping in highly weathered regions. This study, therefore, employed interpretation of aeromagnetic, electromagnetic and radiometric data to better understand the geology, structure networks and the associated alteration which are important in ascertaining the mineralization potential of the site. The results of the work revealed near-surface and basement geology, mineralized structures and alteration zones capable of 
hosting potential gold mineralization in the Konongo Mine. A research by Boadi, Wemegah, \& Preko (2013) which was carried out in the area under consideration was done on a large scale. This work which is on a smaller scale gives the edge to map and enhance subtile variation associated with localised mineralized zones which have previously been delineated. Also, the adoption of the EM data in this work provides it with the more data for reducing the ambiguities that are associated with geophysical data interpretation hence a better decision making (Zhang et al., 2018). This work is very relevant at this time when the topsoil in most of the mining district is contaminated by the small scale "galamsey" making the traditional method of exploration inefficient (Wemegah et al., 2015). This research, therefore, provides baseline data that can be used to revamp the Konongo Mine when supported with ground-based geophysical data such as induced polarization which is useful in identifying sulphide mineralized zones, the main pathfinding mineral of the Birimian Mineralization.

\section{Materials and Methods}

\subsection{Study Area}

The Konongo gold project is located around the coordinate $735,419 \mathrm{~N}$ and $698,988 \mathrm{E}$ in the UTM WGS84 projection system. The area is in the Ashanti Region, about $165 \mathrm{~km}$ northwest of Accra, the capital of Ghana. It is in the semi-equatorial region with bimodal raining seasons. The major season runs from March a to June and the minor season from September to the end of November with a mean annual rainfall of $1465 \mathrm{~mm}$. Daily temperature ranges from $22^{\circ} \mathrm{C}-30^{\circ} \mathrm{C}$, with a mean value of $26^{\circ} \mathrm{C}$ and the mean humidity of $80 \%$. The topography of the area comprises undulating land with elevations of $180-226 \mathrm{~m}$ and circular hill patterns with elevations ranging between 300 to $330 \mathrm{~m}$ above the mean sea level.

\subsection{Geological Settings and Mineralization}

The Konongo gold deposit is found in the Proterozoic Ashanti Greenstone Belt, noted for its rich gold mineralisation in the West African Craton. Geologically, the area is dominated by north-east trending rocks of the Birimian Supergroup consisting of metavolcanic and metasediment units as well as the Tarkwaian Formation and the associated granitoids and dolerite dyke intrusives (Figure 1) (Oberthür, et al., 1994). These formations were deformed, metamorphosed and intruded by syn- and post-granitoids during the Eburnean Orogeny about 2130 $1980 \mathrm{Ma}$ (Griffis et al., 2002; Feybesse et al., 2006). These deformational events have produced a series of northeast-southwest trending shear zones consider to be high angle reverse structures. Generally, the contact between the Birimian metavolcanic and the metasediment is marked by these structures. In the Konongo area, the shear zone is highly folded consisting of two distinct limbs of Birimian rocks which have been folded by a NE trending synclinal fold axis that is in contact with the Banso batholith. The Konongo deposit is hosted by the western limb of this syncline striking north-east (Oberthür et al., 1994; Boadi, We- 
megah, \& Preko, 2013). Also, the area has a series of ENE trending cross-cutting faults. The ENE trending structures are notably more concentrated in the southern portion of the study areas. These structures are associated with a number of shear zones that host major gold mineralization within the Ashanti Greenstone Belt. Hammond and Tabata (1997) reported that the NE structures represent the principal fluid conduits for the mineralization.

Allibone et al. (2002) also reported that the geological structures such as faults, fractures and shear zones play a major role in the epithermal and mesothermal gold mineralization in the Birimian Supergroup. It was also noted that the distribution and the mineralization styles within the units were affected by the reactivation of the structures in the formation throughout the various tectonic episodes (Cozens, 1989; Boadi, Wemegah, \& Preko, 2013).

\subsection{Airborne Geophysical Data Acquisition}

The airborne geophysical datasets namely, magnetic, radiometric and electromagnetic used for the study were acquired by Aerodat Inc., a Canadian airborne geophysical company within the period March 8 to 19, 1995 for Obenemase Gold Mine Limited. The survey was conducted with a Bell 212 helicopter with registration number 9G-ADK, owned by the Ghana National Petroleum Company. The principal sensors used in the data collection included a high sensitivity magnetometer/gradiometer (for magnetic data collection), high sensitivity

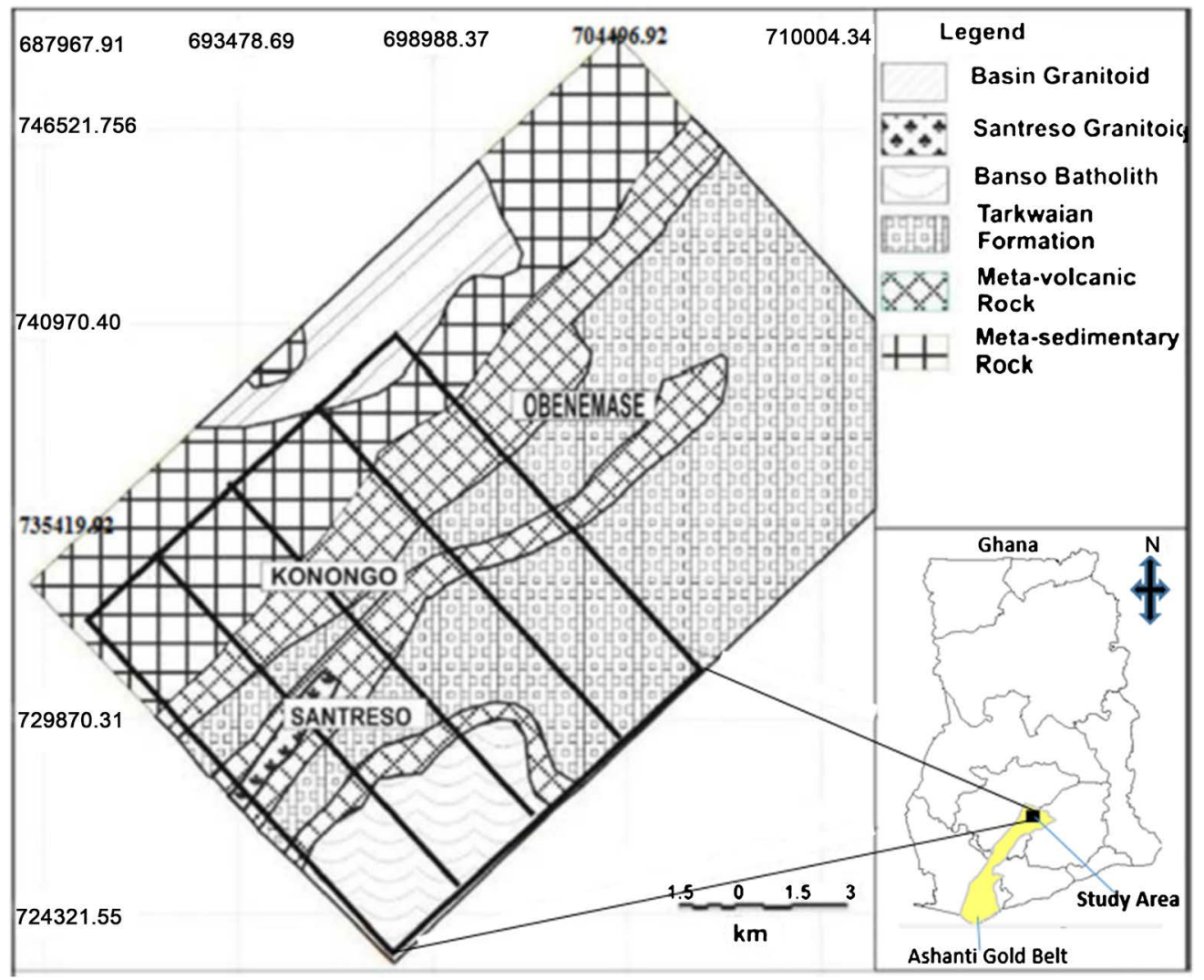

Figure 1. Geological map of the Konongo area (Modified from Boadi, Wemegah, \& Preko (2013)). 
Exploranium Spectrometer (for radiometric data collection) and a five frequency electromagnetic system (for electromagnetic data collection). The survey was conducted using a flight line spacing of $200 \mathrm{~m}$. The terrain clearance was $45 \mathrm{~m}$ for magnetometer/gradiometer and $30 \mathrm{~m}$ for electromagnetic measurements respectively.

\subsection{Data Processing}

\subsubsection{Magnetic Data Processing}

The airborne magnetic data was subjected to pre-processing and post-processing procedures to reduce noise (non-geologic features) in the data. The data were corrected for time lags and heading effects by adjusting the measured magnetic values of the base station. Post-processing of magnetic data was also performed to further enhance the features of interest from the data. The datasets were gridded with the minimum curvature algorithm using one-quarter (1/4) of the profile spacing. The algorithm, which is based on splines in tension (Smith \& Wessel, 1990), substantially increases the smoothness and the lateral consistency of the generated grids (Geosoft Inc., 2008; Wemegah et al., 2017; Takyi-Kyeremeh et al., 2019). In order to enhance and isolate magnetic anomaly features that are of geologic interest, the gridded image of Total Magnetic Intensity (TMI) was subjected to routine series of filters such as reduction to pole (RTP), analytical signal (AS) and first vertical derivative (1VD). Since the study area falls within an area of low magnetic latitude $\left(<10^{\circ}\right.$ declination), the RTP and AS filters were used to transform magnetic anomalies data recorded in the inclined Earth's magnetic field to what the data would have looked like if the magnetic field had been vertical (e.g. Li, 2008). This helps to prevent north-south signals from dominating the data thus removes the dependence of magnetic data on the angle of magnetic inclination and declination (e.g. Nabighian, 1984). The 1VD filter was further applied to RTP grid to enhance large and small scale anomalies and subtler magnetic responses because of their sensitivities to shallow magnetic sources (Telford, Geldart, \& Sheriff, 1990). This filter, therefore, enhances shallow magnetic bodies and sharpens the edges of anomalies.

\subsubsection{Radiometric Data Processing}

In order to obtain radiometric signatures related to the surface geology of the area, radioelement abundance, radioelement ratio and ternary maps were generated (Wemegah et al., 2015; Rani et al., 2019). The distribution of radioactive elements such as Potassium (K), Thorium (eTh) and Uranium (eU) concentration in soil and rocks relate to the differences in lithology of common rocks, alteration and metamorphism processes (Dickson \& Scott, 1997). A ternary map which is a combined composite image of the radioelement abundances with $\mathrm{K}$, eTh and $\mathrm{eU}$ in red, green and blue (RGB) colour model was created. This helps to enhance the lithology and alteration zones associated with the mineralization zones.

\subsubsection{Electromagnetic Data Processing}

The electromagnetic data was processed with high-quality filters to obtain a conductivity anomaly map which was subsequently transformed into an appar- 
ent resistivity anomaly map. The filtering processes were adopted to minimise signal to noise ratio and reject major spheric events. Locally, this spheric activity can produce, sharp and large amplitude events that cannot be removed by conventional filtering techniques. Applying a smoothing or stacking technique helped reduce their amplitude leaving behind broader residual responses. Low pass filter was further applied to enhance the signal to noise ratio. It uses the in-built zero phase shift to prevent any lag or peak displacement in the data (Asiamah, 2004). After the filtering process, a base level correction was applied using EM zero levels during high altitude calibration sequences. The apparent resistivity image was produced from the out-of-phase and in-phase components of the electromagnetic system for all the frequencies $(865 \mathrm{~Hz}, 935 \mathrm{~Hz}, 4175 \mathrm{~Hz}$, $4600 \mathrm{~Hz}$ and $33000 \mathrm{~Hz}$ ). The apparent resistivity was computed using a half-space model of the HEM module in the Geosoft. This model uses inputs comprising the out-of-phase and in-phase components of the secondary field to compute apparent resistivity anomaly map for each used frequency.

\section{Results and Discussion}

Airborne magnetic, radiometric and electromagnetic datasets were used to access the gold mineralization potential of the Konongo Mine located within the gold producing Ashanti Greenstone Belt of Ghana. The research used the different magnetic signatures associated with different rocks due to their varying magnetic susceptibilities as well as different degrees of alteration in the zone of mineralization as well as the structural signatures to map the geology and potential mineralization zones in the area. Similarly, the variation in the concentrations of the three radioelements was employed in the mapping of the various lithological units as well as the zones of hydrothermal alterations which are potential zones of gold mineralization in the Birimian formation. The results of this work revealed near-surface and basement geology, mineralized structures and alteration zones capable of hosting potential gold mineralization in the Konongo Mine's Property.

\subsection{The Magnetic Data}

The magnetic signatures in geological units are caused by differences in the amount of magnetic minerals constituent (mainly, magnetite) of the rock. The magnetic data, therefore, produced magnetic signatures that depend on the magnetic susceptibility responses of the background lithology and other geological processes such as major tectonic activities and the associated geological structures and hydrothermal alterations in the area under study. The application of this method in geological structures mapping is dependence on the amount of magnetic minerals as well as their destruction by hydrothermal alteration, especially along fractured tectonic zones (Plumlee et al., 1992).

Figure 2(a) is the total magnetic intensity image of the study area with magnetic anomalies depicting the various lithological units as well as the associated 
tectonic structures in the study area. It is worth noting from this image that the area hosting rocks with low magnetic susceptibilities such as the metasediment (Ms) and the granitoids (BB) which are expected to have high magnetic signature are characterized by a high magnetic signature while the metavolcanic $(\mathrm{Mv})$ exhibit low magnetic signatures. This reversal of the observed magnetic signatures is due to the effect of induced magnetization characteristics observed at points of low magnetic latitudes. Due to Ghana's location in area of low magnetic latitude, the rock formations in these areas are magnetized parallel to the Earth's magnetic field, thus causing magnetic anomalies to correlate weakly with exact expected magnetic signatures (Boadi, Wemegah, \& Preko, 2013; Graham, Wemegah, \& Preko, 2014; Wemegah et al., 2015; Takyi-Kyeremeh et al., 2019). In order to locate the observed magnetic anomalies directly over the magnetic sources, the analytical signal, a form of reduction to the pole filter (Nabighian, 1984; Roest, Verhoef, \& Pilkington, 1992; MacLeod, Jones, \& Dai, 1993; Li, 2008; Ansari \& Alamdar, 2009) was applied on the total magnetic intensity (TMI) data. This gives a representation of the magnetic anomalies, which depend on the location of the magnetic sources and not on the magnetization direction, thereby aiding the interpretation (Debeglia \& Corpel, 1997).

The image produced from the Analytical Signal filter is shown in Figure 2(b). The well-defined geological boundaries with their respective expected magnetic signatures are shown. The low magnetic signatures (BMv) at the southern central part in the TMI (Figure 2(a)) which turned as moderate and high magnetic signatures in the Analytical Signal Amplitude (Figure 2(b)) can be interpreted as metamorphosed volcanic rocks with minor sediments. Also shown in Figure 2 (b) is the low-to-moderate magnetic signature region (Ms) corresponding to the metamorphosed sediment with its minor volcanoclastic components. This moderate signature can be attributed to the enhancement of the magnetic signature of the sediment by the volcanoclastic inclusions in the area. The long moderate magnetic variability observed at the northeastern corner of the studied area truncating at the south in the TMI can be attributed to Tarkwaian sediment. Eisenlohr and Hirdes (1992) and Hirdes and Nunoo (1994) stated the Tarkwaian consist of conglomerates which principally composed of Birimian quartz pebbles and volcanoclastics accounting for the magnetic signatures observed in that zone. The low and medium magnetic signature can be attributed to the differences in the composition of magnetic mineral of these two rocks. These units are noted to host the Tarkwa Placer deposit (Griffis et al., 2002). Also, the zone of low to moderate magnetic signature (BB) observed at the southern part of the area corresponds to granitoid intrusive identified as the Banso Batholith. This signature is due to the general low magnetic mineral content of this granitoid unit (Kesse, 1985). Similar features of low to moderate magnetic signatures are evidence at the northern part of the area within the basin sediments which maybe underlain by granite. The central region has been tectonically disturbed by major geological processes such as mineralization, hydrothermal alteration, metamorphism, weathering and tectonic activities producing different directional 
(a)

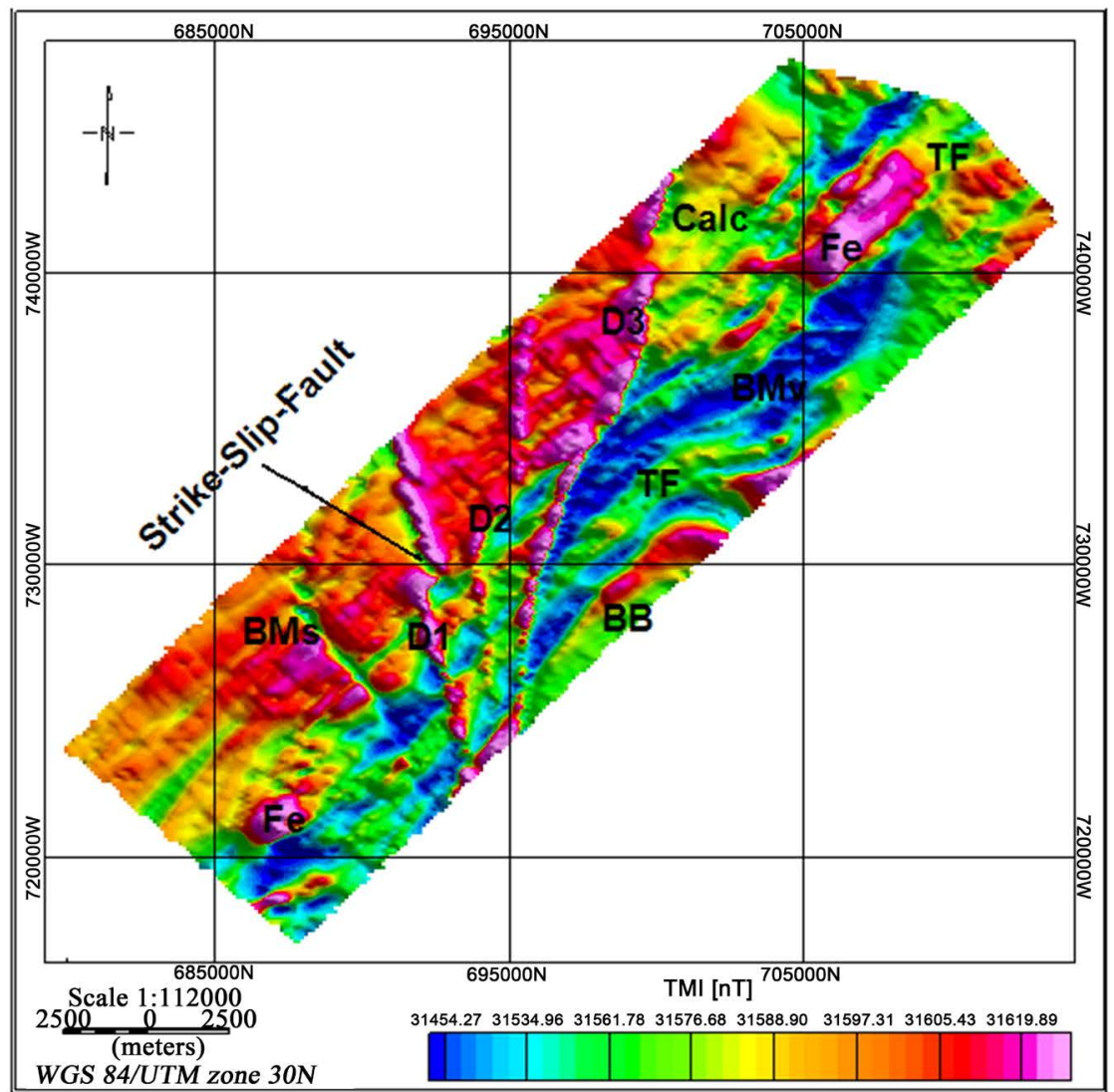

(b)

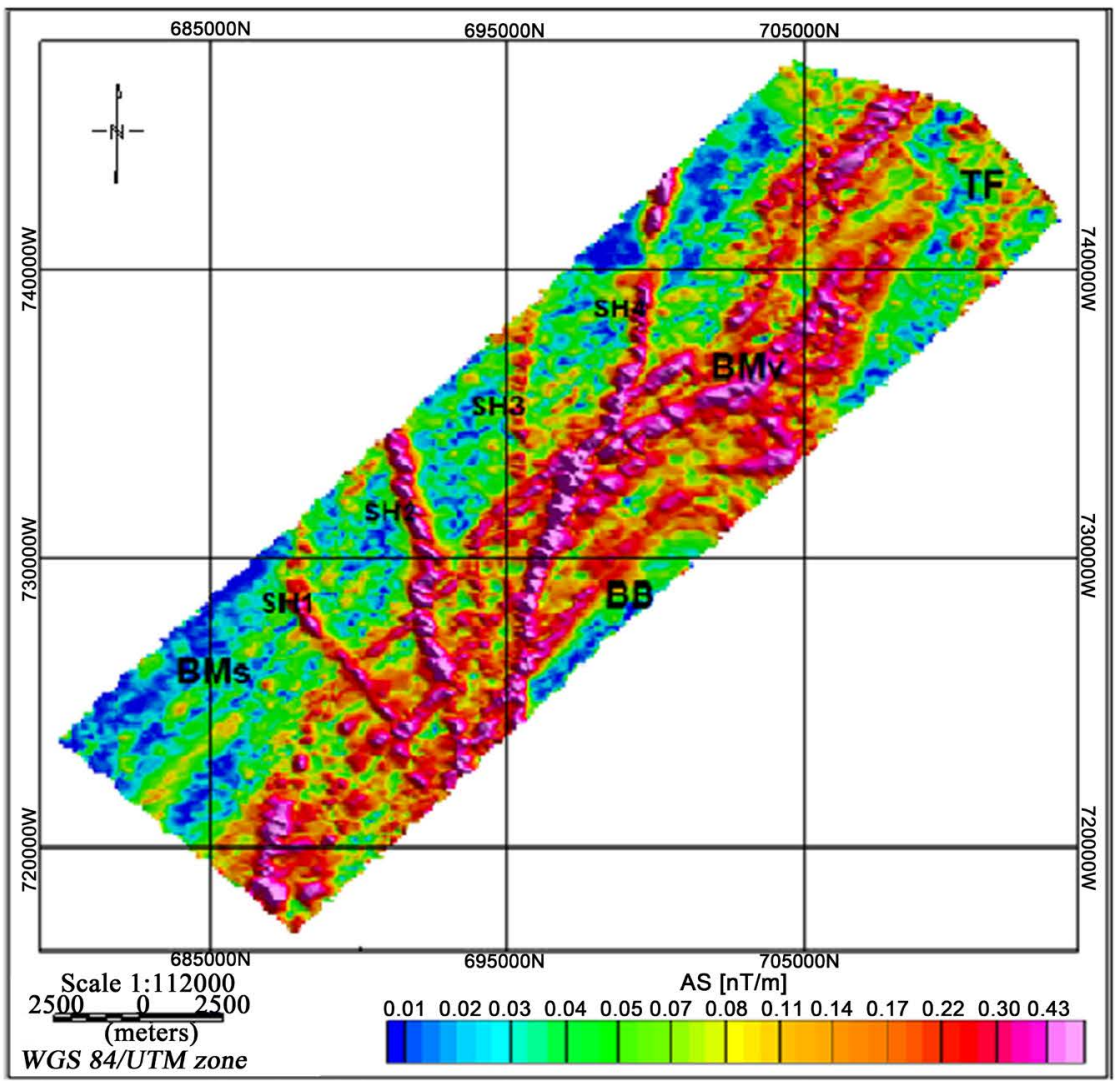

Figure 2. (a) Total magnetic intensity (TMI) Map; (b) Analytical signal map of the TMI. 
trending geological structures.

This region has NE-SW striking geological units which have been fractured, folded, and faulted by a splay of faults. Also observed is the high-intensity magnetic signature trending in NNW-SSE direction, cross-cutting all the mapped geological units in the central part of the area. Agyei-Duodu et al. (2009) and Perrouty et al. (2012) stated that these cross-cutting dykes that are characterised by a well-defined strong magnetic susceptibility and remanence in magnetic data are dolerite dykes. Therefore, the cross-cutting geological features mapped as $\mathrm{DK} 1, \mathrm{DK} 2$ and DK3 are considered to be dolerite dykes. The discontinuity of the dykes observed in the Tarkwain sediments ( $\mathrm{Tf}$ ) is an indication of shearing and faulting (considered to be a strike-slip fault) of the dyke systems in the area. The high magnetic signatures in the TMI at the western limb (Ms) are interpreted as metamorphosed sedimentary rocks with minor mafic intrusions. The most significant concentrations of possible mineralization zones are related to high amplitudes of analytical signal (DK1, DK3, Mv, etc.). The high analytical signal amplitudes as seen in the Birimian metavolcanics (Mv) and Tarkwain sediments correspond to geological structures.

The first vertical derivative filter revealed enhanced magnetic lineaments (Figure 3(a)) that are associated with major geological structures, intrusive dyke systems and also gives the magnetic signature of the various rocks in the area. A typical example of this is the elongated and structural deformation of folded metavolcanic rocks and the Tarkwaian Formation at the central part of the study area. The major dyke structures DK1, DK2 and DK3 (Figure 2(b) and Figure 3(a)) trend mainly in NNW-SSE and NNE-SSW directions and cut across the Tarkwaian Formation and the Birimian Supergroup. The dykes also show signs of shearing indicating a pre-tectonic intrusion with a strike-slip fault noted on DK1 (Figure 2(a)). The dykes were considered to be a late-stage dolerite dyke system (Milési et al., 1992; Oberthuer et al., 1997; Griffis et al., 2002) rocks units and split into three different branches to the north. Furthermore, most of the trends of the delineated structures are in the NE-SW direction, the main structural direction of the Birimian formation. Notable among these is the fault defining the western boundary of the metasediment and the metavolcanic units which form part of the regional Ashanti fault. Griffis et al. (2002) noted that these structural lineaments serve as conduits for hydrothermal fluids which are the main source of primary gold mineralization in the formation. Figure 3(b) shows the delineated lithological units in the area. These rocks include Birimian metasediment, metavolcanic, Tarkwaian Formation, the granitoid intrusions and the dyke network.

\subsection{The Radiometric Data}

In the radiometric anomaly maps (Figure 4), a number of radioelements anomalies are evident with varying degrees of potassium (K), Thorium (eTh) and Uranium (eU) contents, reflecting different physical and chemical processes, 

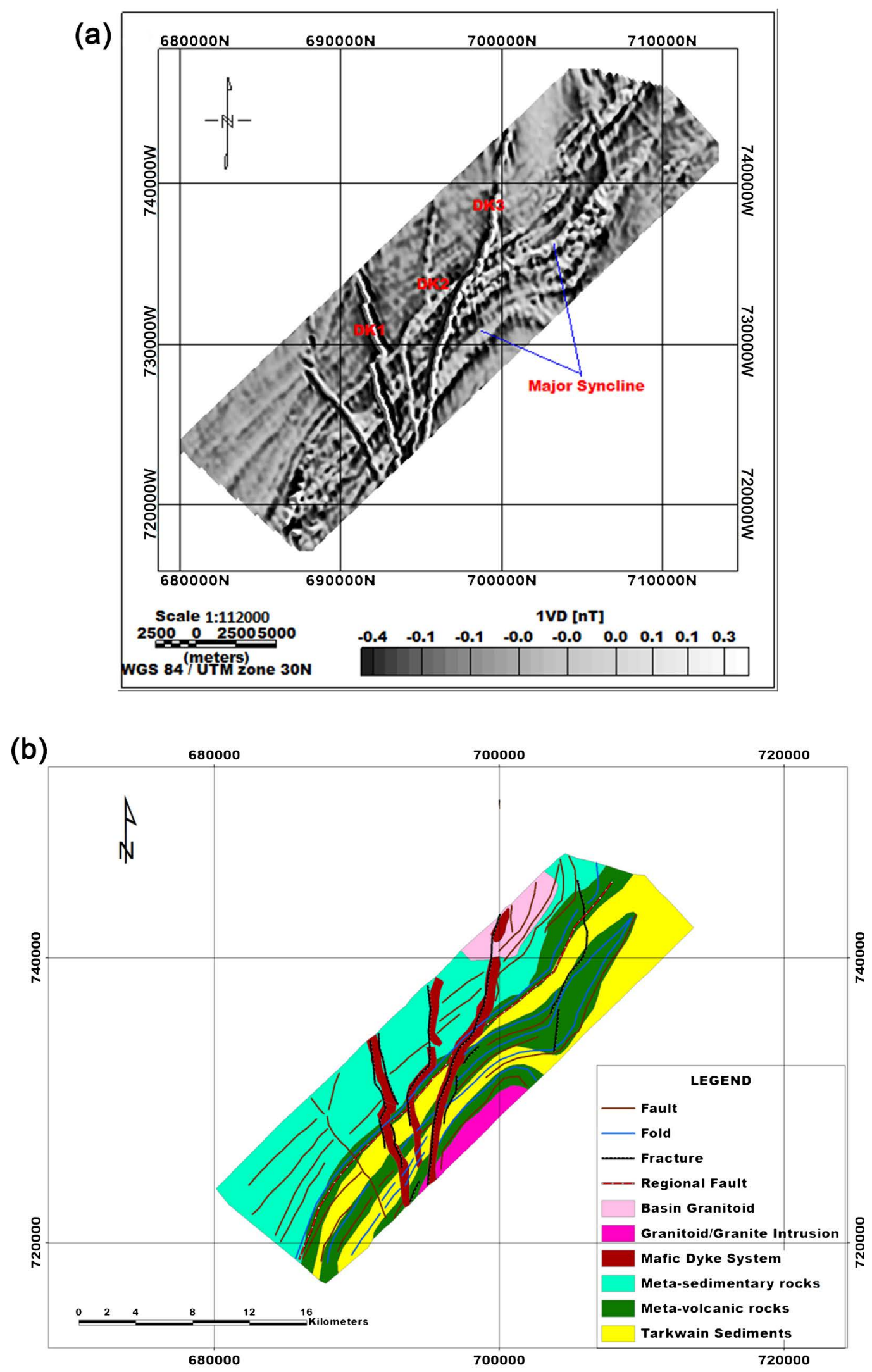

Figure 3. (a) $1^{\text {st }}$ vertical derivative map of RTP; (b) Proposed geological map of Konongo from Airborne Magnetic Data. 

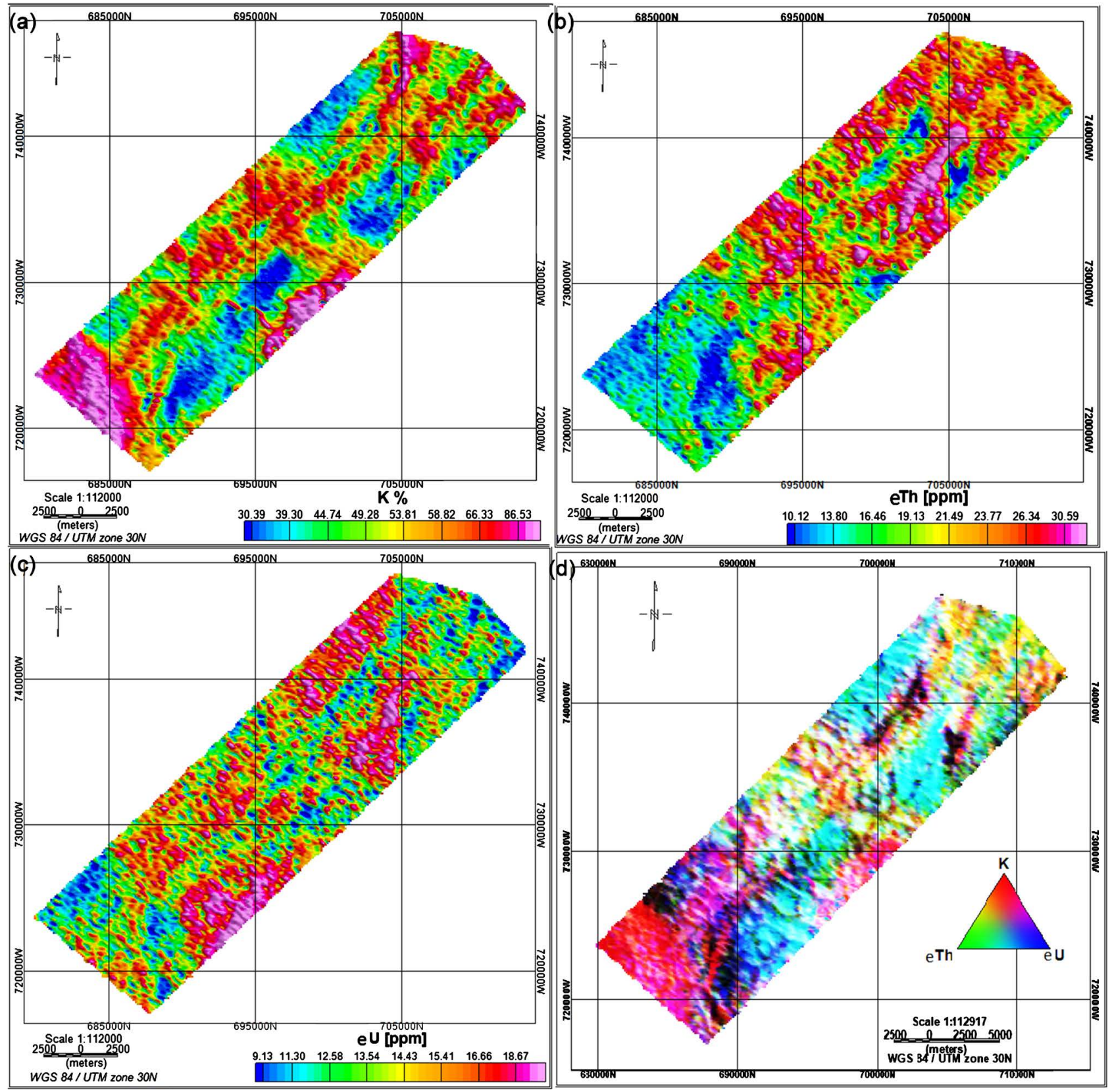

Figure 4. Radiometric maps (a) Potassium concentration; (b) Thorium; (c) Uranium concentration and (d) Ternary map.

lithology and alteration zones in the study area. The high potassium signatures are shown in the southwestern (Fv) and southern (BB) sections of the area (Figure 4(a)) are attributed to granitoid rock; due to its high level of K-feldspar. The low $\mathrm{K}$ activities and high eU and eTh are evident in the central section (Ms) and northwestern part (Mv). Depletion of K content and enrichment of eTh and $\mathrm{eU}$ concentrations indicated the high proportion of the volcanoclastic component of the Birimian metasediment. The high $\mathrm{K}$ concentration along the major Ashanti fault zone can be attributed to intense hydrothermal alteration and metamorphic processes of the structural zone which could be a potential mineralization zone in the area (Boadi, Wemegah, \& Preko, 2013; Wemegah et al., 2015; 
Takyi-Kyeremeh et al., 2019). This is due to the fact that $\mathrm{K}$ concentrations generally increased with increasing weathering processes (Takyi-Kyeremeh et al., 2019). The high $\mathrm{K}$ signature identified in the southern part of the area (Figure 4(a) and Figure 4(d)) which also produced low eTh and eU signatures (Figure 4(b) and Figure 4(c)) occurs at the foot of a hill and can be attributed to a weathered regolith or alluvial deposits. The high $\mathrm{K}$ content in the sediments is believed to be produced by weathered materials from the granitoid. The metavolcanic components of the Birimian (BMv) rocks generally have low $\mathrm{K}$, high $\mathrm{eU}$ and $\mathrm{eTh}$.

In order to further enhance the lithology and alteration zones associated with mineralization, a ternary map (Figure 4(d)) was generated. This map shows strong spatial correlations with the known geological units in the area. The ternary map (Figure 4(d)), relates well to the geology and hydrothermally altered zones of the research area. Some of the notable rock units in this map is the magnetite-rich BMv represented in cyan (Figure 4(d)). These rock units are also prominent in both eU and eTh maps (Figure 4(b) and Figure 4(c)). Other notable units are the metasediment that produced a strong $\mathrm{K}$ signature as well as traces of eU signatures. Similarly, the massive high $\mathrm{K}$ concentration at the southern section of the image is attributed to K-feldspar rich weathered alluvial regolith. Significant high eTh signature with the associated depletion in $\mathrm{K}$ and $\mathrm{eU}$ concentration observed in the north of the site is likely due to the intense weathering processes leading to the accumulation of more resistive Fe rich oxides. These $\mathrm{Fe}$ oxides are mainly of ferruginous laterite as well as duricrusts. Dickson and Scott (1997) reported that unconsolidated ferruginous sands and as well as cemented pisolitic iron duricrusts produced high eTh values. The silcretes and ferruginous regolith also have cyan colour showing higher eTh and $\mathrm{eU}$ signatures with low $\mathrm{K}$ signature. These signatures are due to the eTh association with resistant minerals (e.g. zircon).

The regions with high $\mathrm{K}$ and eTh signatures with corresponding low eU signatures are attributed to expose granites and largely identified at the northeast and the central parts of the ternary image. There is also a record of high $\mathrm{K}$, eTh and $\mathrm{eU}$ signatures in the southern section where in situ weathering sediments are deposited. These responses reflect the high radioelement concentrations of the parent rocks. The areas of high $\mathrm{eU}, \mathrm{eTh}$ and $\mathrm{K}$ signatures in the basin can be attributed to the presence of granitoids complexes. Generally, rocks with high $\mathrm{K}$-feldspar composition in the areas record high $\mathrm{K}$ signatures. The interpreted geology of the area as deduced from the radiometric datasets is shown in Figure 5.

\subsection{Electromagnetic Data}

The results of high resolution airborne electromagnetic survey (Figure 6(a)) provide information on the concealed geological structures and possible conductive minerals like the disseminated sulphide. The results showed good conductive responses at contact zones between the metasediment and metavolcanic units which may be due to fracture zones with probably graphitic phyllite and 


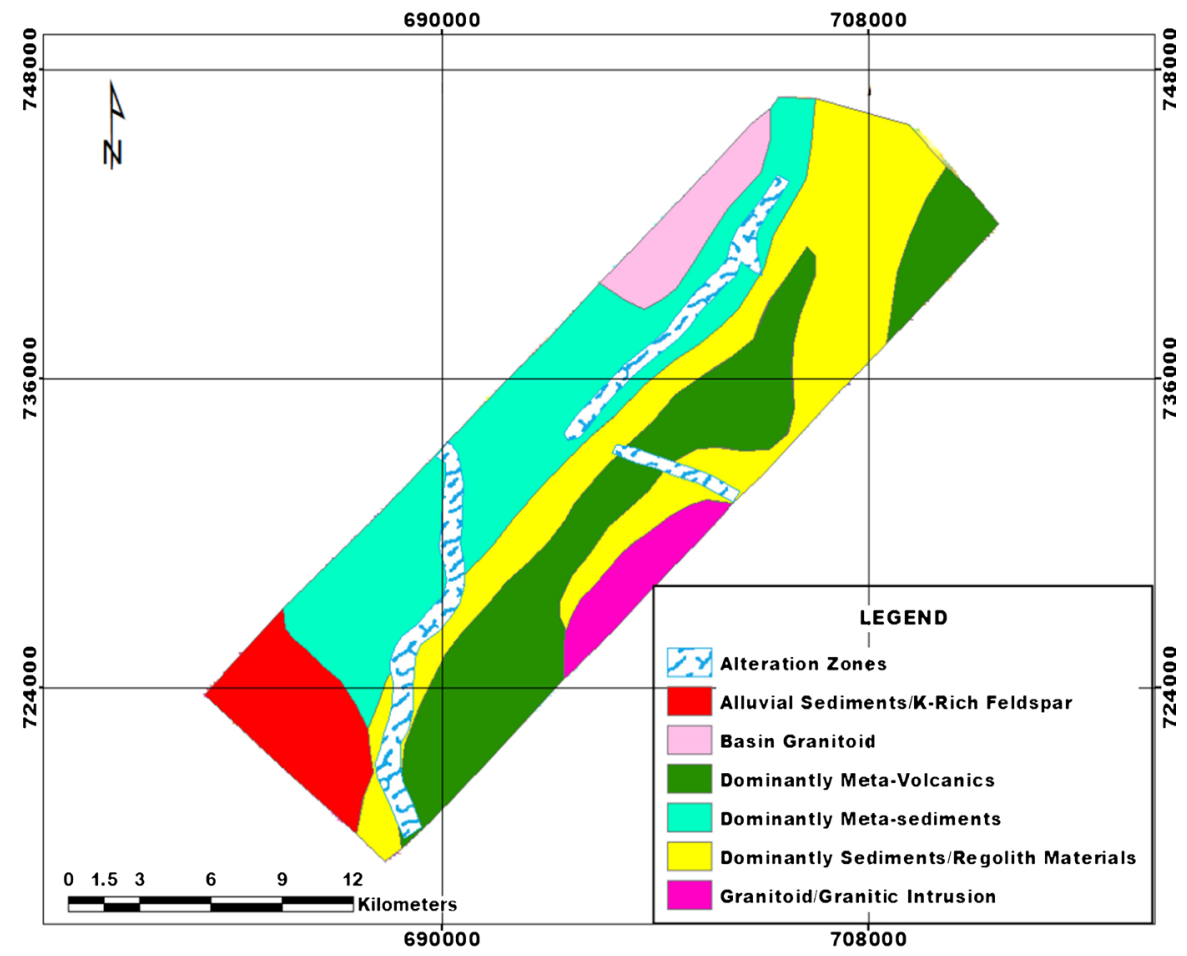

Figure 5. Geology of Konongo Mine deduced from the Airborne Radiometric Data.
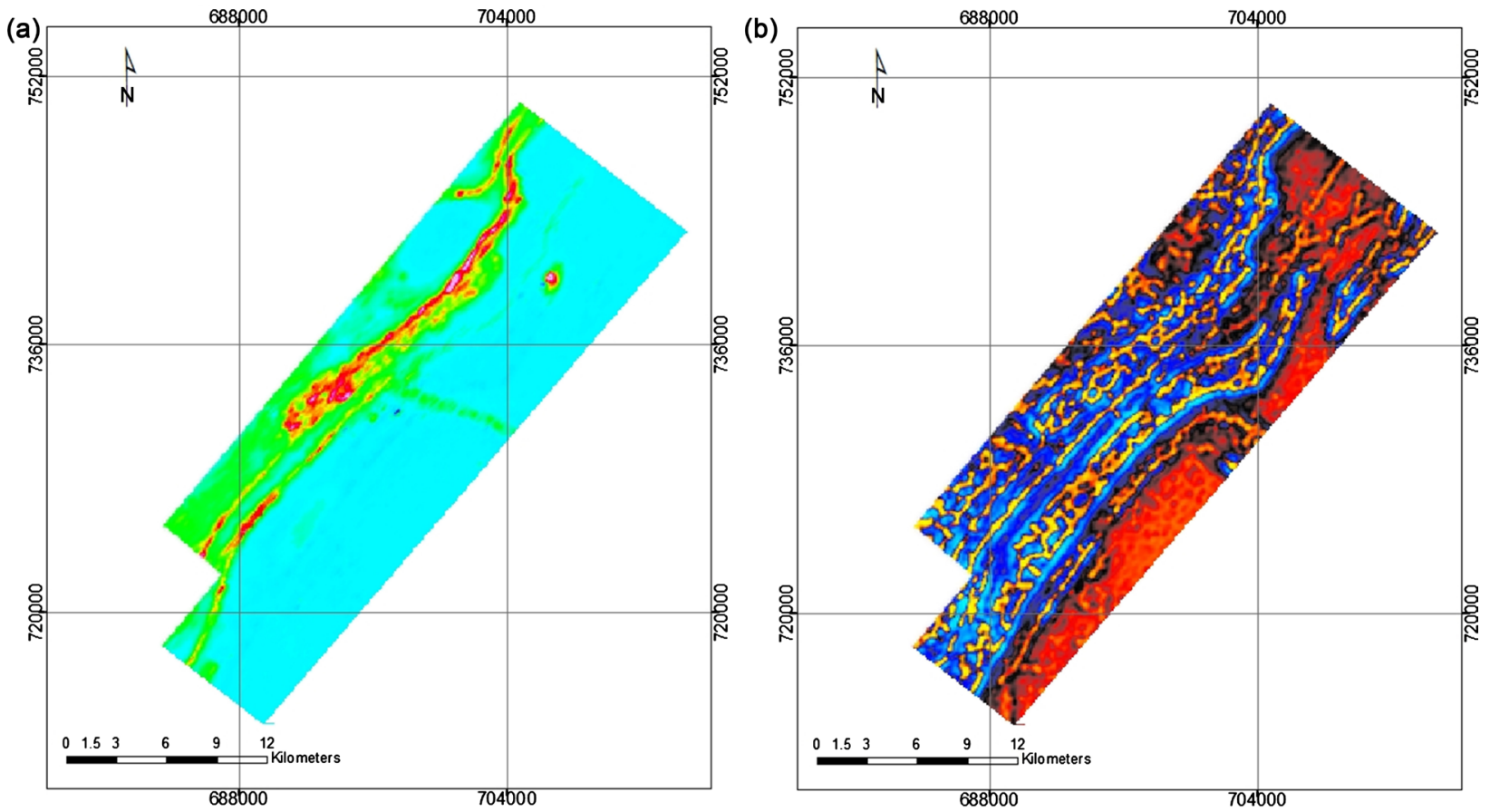

Conductivity $(\Omega)$

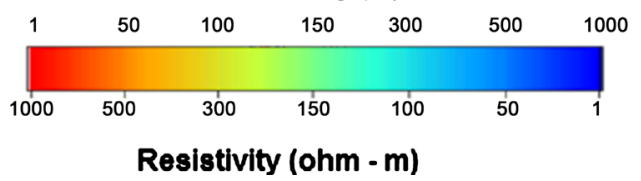

Figure 6. (a) Electrical conductivity; (b) Electrical resistivity anomaly maps deduced from the frequency dependence electromagnetic data. 
sulphidation (Airo, 2015) which are associated with gold mineralization in the Birimian (Oberthür et al., 1994; Griffis et al., 2002). The weak signatures may represent an abrupt lateral change in resistivity. This may be related more to changes in surficial conditions rather than changes in the bedrock. In order to yield a higher resolution of geologic features, the EM anomaly map was converted into resistivity anomalies (Huang \& Fraser, 2003) using a half-space inversion method. Figure 6(b) shows a low frequency $(865 \mathrm{~Hz})$ EM anomaly map converted into a resistivity anomaly map. The high resistivity signatures in the north-eastern section of the area in the resistivity map (Figure 6(b)), corresponding to consolidated igneous rocks (e.g. Banso Batholith). Moderate resistivities signatures represent structural evolution at deeper depths and are dominant within the metasediment and metavolcanic units. Continuously low resistivity areas are evident at contact zones between the rock units, representing major fault planes in the area which correspond to what was seen in the magnetic data (Figure 3(a) and Figure 4).

These features indicate preferred host for lode gold deposits in the greenstone belt. At the faulting plane that separates the metasediment and metavolcanic, shearing of rocks becomes very pronounced, thus providing structural corridors for a hydrothermal alteration system. Generally, the apparent resistivity anomaly map showed the overall distribution of major rock units and structure lineaments. The shear structures formed zones of intensive deformation, folding and faults are trending in the NE-SW direction. This shear zones occurring at the contact between the belt and the basin margins are a potential host of gold mineralization as similar features host gold in mines operating in most parts of the Ashanti Greenstone Belt (Perrouty et al., 2012; Takyi-Kyeremeh et al., 2019). These structures serve as a conduit for the transportation of hydrothermal fluids and possible mineralization in the area (Keller, 1987; Palacky, 1987; Ford, Keating, \& Thomas, 2007). The highly conductive or low resistivity nature of these zones could be attributed to argillic alteration, increased rock porosity, graphite and sulphidation which are major pathfinders for gold mineralization within the Birimian formation as well as fractures containing fluids. Fracture openings and pore spaces containing fluid increase conductivity of the host rocks. Interpreted geological map of the study area delineated from electromagnetic data is shown in Figure 7.

\subsection{Integrated Geological and Structural Map of the Study Area}

Integration of the interpreted airborne geophysical datasets provides new insight into the geological structures, hydrothermal alterations and geology of the study area. The geology consists of basement rocks, structures, intrusive bodies, chemical sediments and surficial materials including weathered sediments, regolith, duricrusts, thick saprolite, volcaniclastics rock units formed through a number of geological processes, including metamorphism, tectonic activities, weathering and erosion. The main geological units mapped in the area consists of the Birimian 


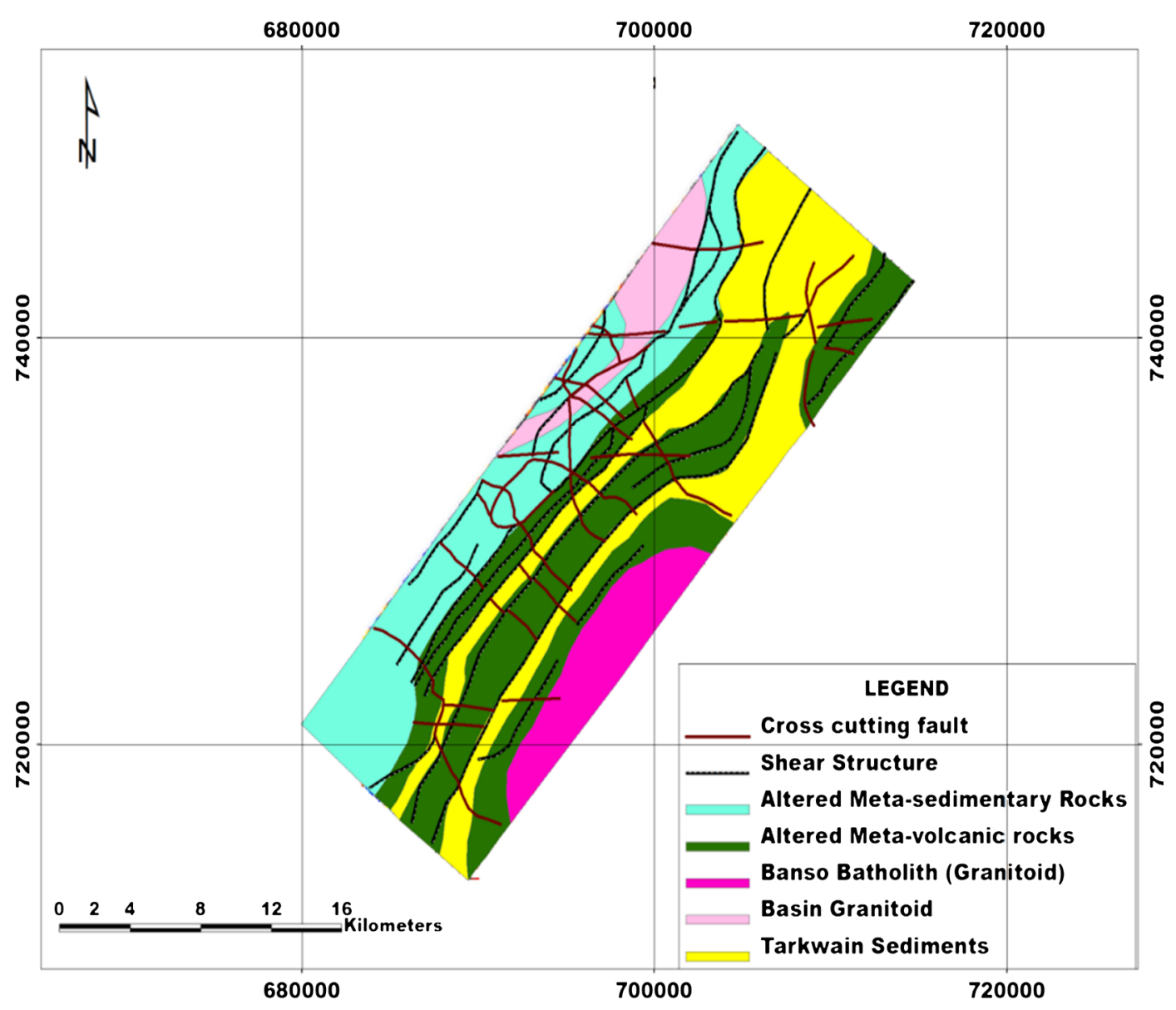

Figure 7. Interpreted geological map of Konongo Mine deduced from the electromagnetic data.

metasediment and metavolcanic rocks the Tarkwaian Formation and associated intrusive bodies like granites, dykes and sills which were observed to be highly metamorphosed and complex (Kleinschrot et al., 1994; John et al., 1999; Kuma et al., 2010). The analysis of the azimuth frequency using a rose diagram (Figure $8(\mathrm{~b})$ ), revealed that the mapped lineaments are trending in the N-S, NNW-SSE, NNE-SSW and NE-SW directions. The petals in azimuth frequency NE-SW and NNE-SSW direction represent the main strike directions of the geological structures in the study area. Out of total azimuth values, $90 \%$ of the lineaments strikes in $30^{\circ}-60^{\circ}$ directions; which represent regional strikes of the studied area. The other $10 \%$ of azimuth values strike in N-S and NNW-SSE directions are representing the D1 and D4 deformational events respectively (Perrouty et al., 2012). Oberthür et al. (1997) noted that the deformation event produced major deformation in the metavolcanic under greenschist metamorphic condition. The mapped NNE-SSW to NE-SW trending faults, considered to be D6 tectonic deformation events (Perrouty et al., 2012) are notably more concentrated along tectonic contact zones between the metasediment, metavolcanic and the Tarkwain Formation. The D6 structures in the area show signs of a shortening phase producing regional scale folding at the Birimian, the Tarkwaian and the Banso batholith contact. 
(a)

(a)

680000

700000

720000

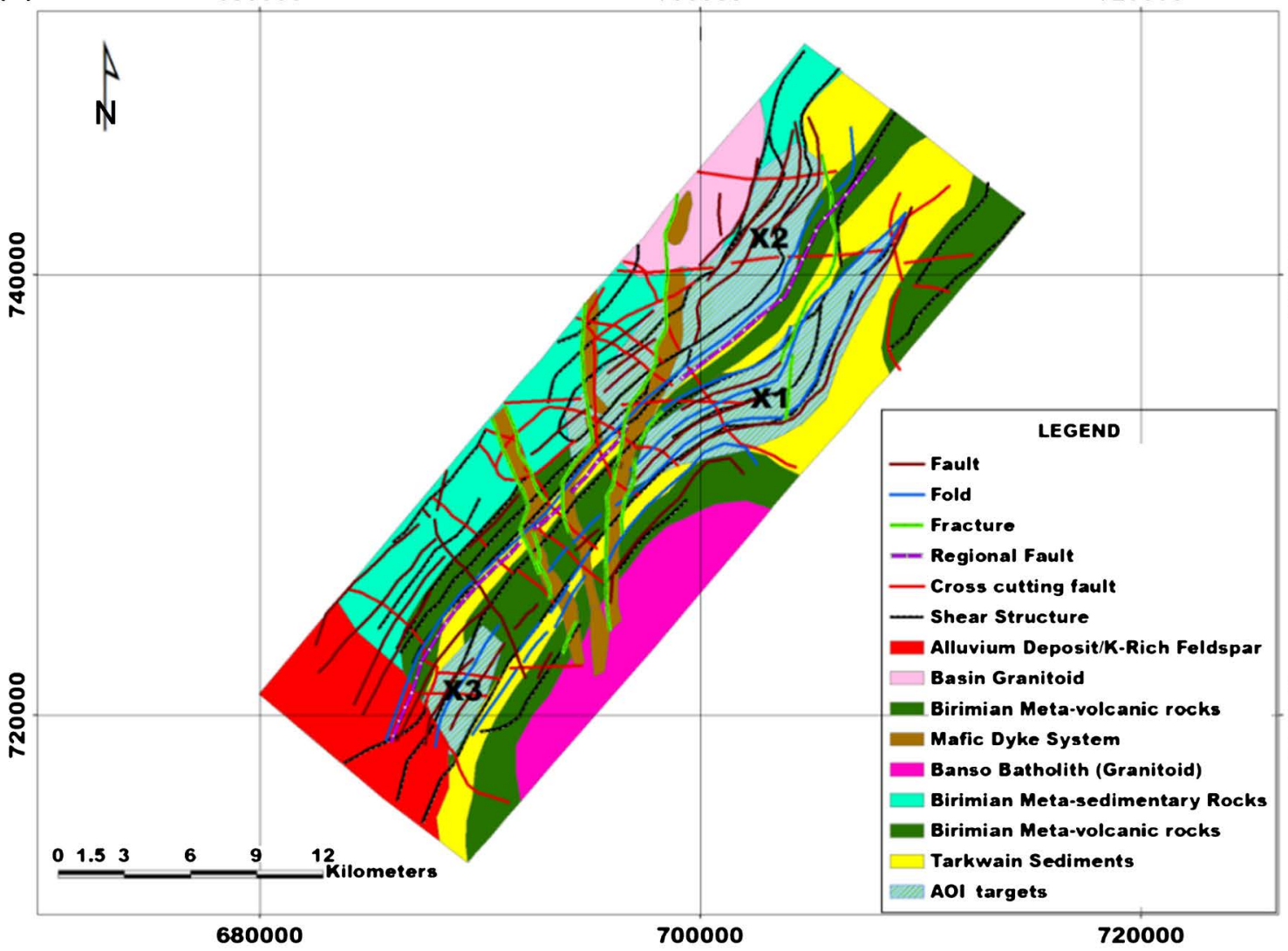

$\stackrel{2}{\circ}$

(b)

$\mathrm{N}$

$0^{\circ}$

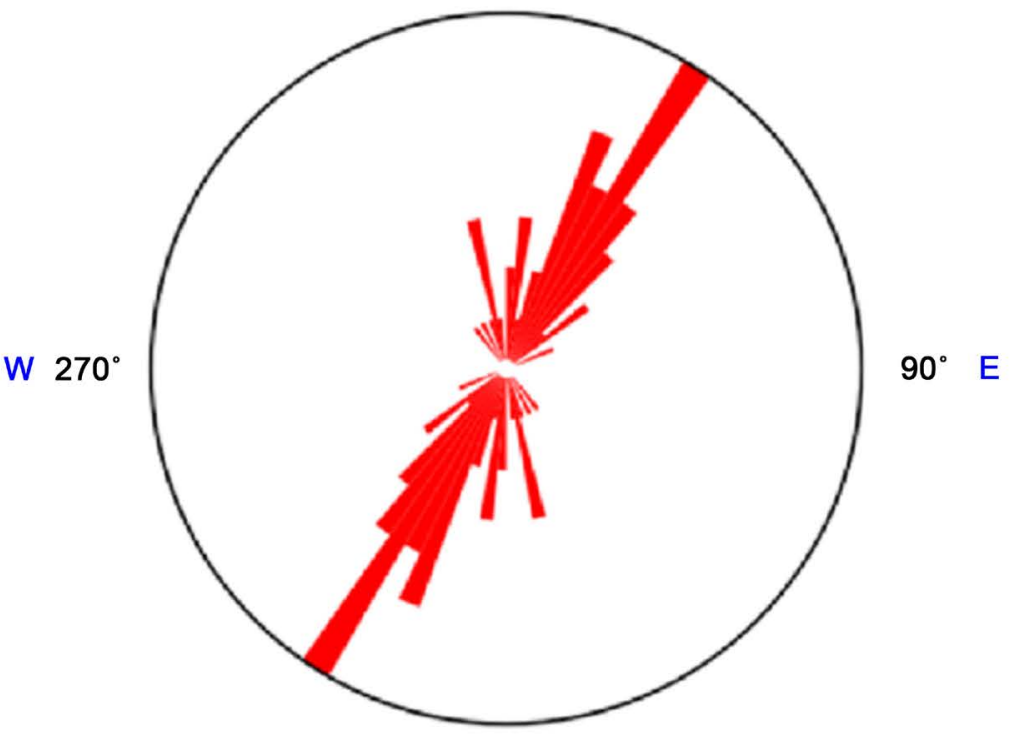

$180^{\circ}$

$\mathrm{S}$

Figure 8. (a) Proposed geology and gold targets areas of the Konongo Mine; (b) Rose diagram of the structural trends. 


\section{Signatures of Gold Mineralization and Rock Alteration}

Evidence of rock alterations that are associated with gold mineralization is best observed in the geophysical signatures of the bedrocks and tectonic contact zones. In the magnetic anomalies, these zones were observed as zones of weaker magnetic signatures due to the geochemical alteration of the magnetic minerals. In the study area where alterations are mainly of low-grade metamorphism (greenschist) (Griffis et al., 2002), the reduction in the magnetic signature can be attributed to the destruction of highly magnetic minerals such as magnetite to low magnetic minerals. In the resistivity anomaly map, evidence of fluid alterations is clearly seen as highly conductive zones in the contact zones particularly, within metasediment and metavolcanic (Figure 6(b)). These high conductive regions may be due to chemical sediments, graphite, sulphide-bearing sediments associated with the hydrothermal alteration activities. In the radiometric data, signatures of $\mathrm{Au}$ deposits are very variable with $\mathrm{K}$-content. Increasing $\mathrm{K}$ concentration and decreasing eTh concentration at the contact zones between metasediment and metavolcanic provides an indication of hydrothermal alteration zones. This evidence of rock alterations indicates potential sites for gold mineralization in the areas, mainly along the major faults which serve as conduits for the movement of the hydrothermal fluids. Hammond and Tabata (1997) stated that the NE-SW and the NNE-SSW structures serve as the principal fluid conduits during the mineralization occurrence with the Birimian formation which aid in the alteration process. Oberthür et al. (1997) and SEMS (2006) stated that the NNE-SSW and NE-SW within the Birimian host major rich pyrite and fine grain arsenopyrite and associated with gold deposits in the area. These zones also produced strong conductivity signatures in the EM data at the metasediment-metavolcanic contact (Figure 6(a) a sign of high conductive pyrite and arsenopyrite, thereby making these areas potential gold mineralization zones. The potential zones of gold mineralization in Konongo Mine Concession from combined geology, structural networks and altered zones are shown in Figure 8(a). The mapped mineralized zone, X2 is located along a tectonic contact zone, at the regional fault, between the volcanic belt and basin sediment. The mineralized zone $\mathrm{X} 1$ is within a sequence of metavolcanic and metasedimentary units. Also, known quartz-vein style mineralization, situated along with a NE-SW trending tholeiitic metavolcanic rocks. The zone $\mathrm{X} 3$ is also located on the extent of the regional fault located in the belt. This zone is characterized by the presence of sediments rich in regolith materials (Figure 4(a) and Figure 5) which are associated with alluvial gold deposits.

\section{Conclusion}

Integrated geophysical datasets of airborne magnetic, radiometric and electromagnetic surveys for the Konongo Mine Concession provide useful information about the lithology, geological structures and hydrothermal alterations, linked with potential gold mineralization zones in the area. The radiometric anomalies 
provided information on the surface geology which reflects the regolith as well as the degree of alteration in the area. The aeromagnetic signatures revealed basement rocks and hidden structures whereas the electromagnetic anomalies delineated sulphide minerals, lithology and mineralized structures of the Konongo mine. The geology of the Konongo mine is found to consist of a series of metavolcanic rock units at the central and eastern part of the area, metasedimentary rocks unit at the western part and Tarkwaian formation in the north-east which widens and truncates in the south where a number of intrusive mafic dyke systems and granitoids are also located. The mapped structures are located mainly at the contact between the various lithological units in the area. These structures include faults and the folding of the Birimian metavolcanic rocks and Tarkwaian formation which trends in the NE-SW direction. The analysis of the structure lineaments reveals three major tectonic events namely, D1, D4 and D6 events. The NE-SW and NNE-SSW trending structures represent the main strike directions and formed $90 \%$ of the delineated structures and N-S and NNW-SSE trending structures forming the remaining $10 \%$. These structures which occur mainly at the contact between the metasediment and the Birimian metavolcanic units, as well as the Tarkwaian Formation with their associated alteration zones and complex dyke systems, are mapped as potential gold mineralization zones.

\section{Acknowledgements}

The authors express sincere gratitude to the Exploration Director, Mr Bill Reid of Signature Metals Limited, Konongo Gold Project, for his immense support in releasing the data for this research.

\section{Funding}

This research is self-funded and highly supported by Signature Metals Limited at Konongo Gold Mine in the world-class Ashanti Greenstone Belt of Ghana.

\section{Conflicts of Interest}

The authors declare no conflicts of interest regarding the publication of this paper.

\section{References}

Agyei-Duodu, J., Loh, G. K., Boamah, K. O., Baba, M., Hirdes, W., Toloczyki, M., \& Davis, D. W. (2009). Geological Survey Department of Ghana (GSD) Report. Geological Map of Ghana 1:1000000, Accra Ghana.

Airo, M.-L. (2015). Geophysical Signatures of Mineral Deposit Types in Finland. Geological Survey of Finland, Special Paper 58, 9-70.

Allek, K., \& Hamoudi, M. (2008). Regional-Scale Aeromagnetic Survey of the South-West of Algeria: A Tool for Area Selection for Diamond Exploration. Journal of African Earth Sciences, 50, 67-78. https://doi.org/10.1016/j.jafrearsci.2007.09.018

Allibone, A., Teasdale, J., Cameron, G., Etheridge, M., Uttley, P., Soboh, A., Appiah-Kubi, 
J., Adanu, A., Arthur, R., \& Mamphey, J. (2002). Timing and Structural Controls on Gold Mineralization at the Bogoso Gold Mine, Ghana, West Africa. Economic Geology, 97, 949-969. https://doi.org/10.2113/gsecongeo.97.5.949

Ansari, A. H., \& Alamdar, K. (2009). Reduction to the Pole of Magnetic Anomalies Using Analytic Signal. World Applied Sciences Journal, 7, 405-409.

Asiamah, G. K. (2004). The South Ashanti Greenstone Belt GEOTEM and Magnetic Survey-Application to Mineral Exploration. In 2004 SEG Annual Meeting. Denver, CO: Society of Exploration Geophysicists. https://doi.org/10.1190/1.1843293

Boadi, B., Wemegah, D. D., \& Preko, K. (2013). Geological and Structural Interpretation of the Konongo Area of the Ashanti Gold Belt of Ghana from Aeromagnetic and Radiometric Data. International Research Journal of Geology and Mining, 3, 124-135.

Cozens, B. (1989). The Geology and Structure of the Konongo Gold Mine, Ghana, and Its Implications in Exploration. In R. W. Le Maitre (Ed.), Pathways in Geology-Essays in Honour of Edwin Sharbon Hills (pp. 439-456). Melbourne: Blackwell.

Debeglia, N., \& Corpel, J. (1997). Automatic 3D Interpretation of Potential Field Data Using Analytic Signal Derivatives. Geophysics, 62, 87-96.

https://doi.org/10.1190/1.1444149

Dickson, B. L., \& Scott, K. M. (1997). Interpretation of Aerial Gamma-Ray Surveys-Adding the Geochemical Factors. AGSO Journal of Australian Geology and Geophysics, 17, 187-200.

Eisenlohr, B. N. W., \& Hirdes, W. (1992). The Structural Development of the Early Proterozoic Birimian and Tarkwaian Rocks of Southwest Ghana, West Africa. Journal of African Earth Sciences, 14, 313-325. https://doi.org/10.1016/0899-5362(92)90035-B

Feybesse, J. L., Billa, M., Guerrot, C., Duguey, E., Lescuyer, J. L., Milési, J. P., \& Bouchot, V. (2006). The Paleoproterozoic Ghanaian Province: Geodynamic Model and Ore Controls, including Regional Stress Modeling. Precambrian Research, 149, 149-196. https://doi.org/10.1016/j.precamres.2006.06.003

Ford, K., Keating, P., \& Thomas, M. D. (2007). Overview of Geophysical Signatures Associated with Canadian Ore Deposits. In W. D. Goodfellow (Ed.), Mineral Deposits of Canada-A Synthesis of Major Deposit-Types, District Metallogeny, the Evolution of Geological Provinces, and Exploration Methods (pp. 939-970). Special Publication No. 5, St. John's, NL: Geological Association of Canada, Mineral Deposits Division.

Geosoft Inc. (2008). Oasis Montaj 7.0 Mapping and Processing System. The Core Software Platform for Working with Large Volume Spatial Data (pp. 50-150). Ontorio.

Graham, K. M., Wemegah, D. D., \& Preko, K. (2014). Geological and Structural Interpretation of Part of the Buem Formation, Ghana, Using Aerogeophysical Data. Journal of Environment and Earth Science, 4, 17-31.

Griffis, R. J., Barning, K., Agezo, F. L., \& Akosah, F. K. (2002). Gold Deposits of Ghana (pp. 7-12, 19-37, 163-169). Minerals Commission Report.

Gunn, P. J., \& Dentith, M. C. (1997). Magnetic Responses Associated with Mineral Deposits. AGSO Journal of Australian Geology and Geophysics, 17, 145-158.

Hammond, N. Q., \& Tabata, H. (1997). Characteristics of Ore Minerals Associated with Gold at the Prestea Mine, Ghana. Mineralogical Magazine, 61, 879-894.

https://doi.org/10.1180/minmag.1997.061.409.10

Hirdes, W., \& Nunoo, B. (1994). The Proterozoic Paleoplacers at Tarkwa Gold Mine, SW Ghana: Sedimentology, Mineralogy, and Precise Age Dating of the Main Reef and West Reef, and Bearing of the Investigations on Source Area Aspects. Geologisches Jahrbuch $D, 100,247-311$. 
Huang, H. \& Fraser, D. C. (2003). Inversion of Helicopter Electromagnetic Data to a Magnetic Conductive Layered Earth. Geophysics, 68, 1211-1214.

https://doi.org/10.1190/1.1598113

Jaques, A. L., Wellman, P., Whitaker, A., \& Wyborn, D. (1997). High-Resolution Geophysics in Modern Geological Mapping. AGSO Journal of Australian Geology and Geophysics, 17, 159-173.

John, T., Klemd, R., Hirdes, W., \& Loh, G. (1999). The Metamorphic Evolution of the Paleoproterozoic (Birimian) Volcanic Ashanti Belt (Ghana, West Africa). Precambrian Research, 98, 11-30. https://doi.org/10.1016/S0301-9268(99)00024-8

Keller, G. V. (1987). Rock and Mineral Properties. In M. C. Nabighian, (Ed.), Electromagnetic Methods in Applied Geophysics: Part A (pp. 13-52). Tulsa, OK: Society of Exploration Geophysicists.

Kesse, G. O. (1985). The Mineral and Rock Resources of Ghana. Geological Survey Department 642 A.A., Rotterdam: Balkema.

Kleinschrot, D., Klemd, R., Brocker, M., Okrusch, M., Franz, L., \& Schmidt, K. (1994). Protores and Country Rocks of the Nsuta Manganese Deposit. Neues Jahrbuch Mineral, 168, 67-108.

Kuma, J. S., Kim, Y. U., Boamah, D., \& Sakamoto, I. (2010). Gold Potential of the Ashanti Belt of Ghana. Journal of the School Marine Science and Technology, Tokai University, $8,25-39$.

Li, X. (2008). Magnetic Reduction-to-the-Pole at Low Latitudes: Observations and Considerations. The Leading Edge, 27, 990-1002. https://doi.org/10.1190/1.2967550

MacLeod, I. N., Jones, K., \& Dai, T. F. (1993). 3-D Analytic Signal in the Interpretation of Total Magnetic Field Data at Low Magnetic Latitudes. Exploration Geophysics, 24, 679-688. https://doi.org/10.1071/EG993679

Milési, J. P., Ledru, P., Feybesse, J. L., Dommanget, A., \& Marcoux, E. (1992). Early Proterozoic Ore Deposits and Tectonics of the Birimian Orogenic Belt, West Africa. Precambrian Research, 58, 305-344. https://doi.org/10.1016/0301-9268(92)90123-6

Morgan, L. A. (2012). Geophysical Characteristics of Volcanogenic Massive Sulphide Deposits in Volcanogenic Massive Sulphide Occurrence Model: U.S. Geological Survey Scientific Investigations Report 2010-5070-C.

Nabighian, M. N. (1984). Toward a Three-Dimensional Automatic Interpretation of Potential Field Data via Generalised Hilbert Transforms: Fundamental Relations. Geophysics, 49, 780-789. https://doi.org/10.1190/1.1441706

Oberthür, T., Vetter, U., Schmidt Mumm, A., Weiser, T., Amanor, J. A., Gyapong, W. A., Kumi, R., \& Blenkinsop, T. G. (1994). The Ashanti Gold Mine at Obuasi, Ghana: Mineralogical, Geochemical, Stable Isotope and Fluid Inclusion Studies on the Metallogenesis of the Deposit. Geologisches Jahrbuch, 100, 31-129.

Oberthür, T., Weiser, T., Amanor, J. A., \& Chryssoulis, S. L. (1997). Mineralogical Siting and Distribution of Gold in Quartz Veins and Sulphide Ores of the Ashanti Mine and Other Deposits in the Ashanti Belt of Ghana: Genetic Implications. Mineralium Deposita, 32, 2-15. https://doi.org/10.1007/s001260050068

Oliver, B. (2009). Report, Development Strategy Konongo Gold Project: A New Gold Project in the World-Class Ashanti Gold Belt of Ghana. Victoria, Australia: Signature Metals Ltd.

Palacky, G. J. (1987). Resistivity Characteristics of Geologic Targets. In M. N. Nabighian (Ed.), Electromagnetic Methods in Applied Geophysics Theory: Tulsa, Okla (Vol. 1, pp. 53-122). Society of Exploration Geophysicists. 
Perrouty, S., Aillères, L., Jessell, M. W., Baratoux, L., Bourassad, Y., \& Crawford, B. (2012). Revised Eburnean Geodynamic Evolution of the Gold-Rich Southern Ashanti Belt, Ghana, with New Field and Geophysical Evidence of Pre-Tarkwaian Deformations. Precambrian Research, 204-205, 12-39.

https://doi.org/10.1016/j.precamres.2012.01.003

Plumlee, G., Smith, K. S., Ficklin, W., \& Briggs P. H. (1992). Geological and Geochemical Controls on the Composition of Mine Drainages and Natural Drainages in Mineralized Areas. In Proceedings of 7th International Water-Rock Interaction Conference (pp. 419-422). Park City, UT.

Porwal, A., Carranza, E. J. M., \& Hale, M. (2006). A Hybrid Fuzzy Weights-of-Evidence Model for Mineral Potential Mapping. Natural Resources Research, 15, 1-14. https://doi.org/10.1007/s11053-006-9012-7

Rani, K., Guha, A., Mondal, S., Pal, S. K., \& Kumar, K. V. (2019). ASTER Multispectral Bands, Ground Magnetic Data, Ground Spectroscopy and Space-Based EIGEN6C4 Gravity Data Model for Identifying Potential Zones for Gold Sulphide Mineralization in Bhukia, Rajasthan, India. Journal of Applied Geophysics, 160, 28-46. https://doi.org/10.1016/j.jappgeo.2018.10.001

Reidy, P. (2012). Lion Gold Corp. Ltd. Report: Competent Persons Report-Konongo Gold Project Ghana. Auralia: Auralia Conducted by Mining Consulting Pty Ltd.

Roest, W. R., Verhoef, J., \& Pilkington, M. (1992). Magnetic Interpretation Using the 3-D Analytical Signal. Geophysics, 57, 116-125. https://doi.org/10.1190/1.1443174

SEMS Exploration Ltd. (2006). North Ashanti Gold Project Ghana, West Africa. Resource Report, Accra, Ghana. AMI Resources Inc.

Smith, W. H. F., \& Wessel, P. (1990). Gridding with Continuous Curvature Spline in Tension. Geophysics, 55, 293-305. https://doi.org/10.1190/1.1442837

Takyi-Kyeremeh, K. Wemegah, D. D., Preko, K., \& Menyeh, A. (2019). Integrated Geophysical Study of the Subika Gold Deposit in the Sefwi Belt, Ghana. Cogent Geoscience, 5, 1-16. https://doi.org/10.1080/23312041.2019.1585406

Taylor, G., \& Eggleton, R. A. (2001). Regolith Geology and Geomorphology. Hoboken, NJ: John Wiley \& Sons.

Telford, W. M., Geldart, L. P., \& Sheriff, R. E. (1990). Applied Geophysics (2nd ed.) Cambridge: Cambridge University Press. https://doi.org/10.1017/CBO9781139167932

Thomas, M. D., Walker, J. A., Keating, P., Shives, R., Kiss, F., \& Good-fellow, W. D. (2000). Geophysical Atlas of Massive Sulphide Signatures, Bathurst Mining Camp, New Brunswick. Geological Survey of Canada Open File 3887, New Brunswick Department of Natural Resources and Energy, Minerals and Energy Division Open File 2000-4. https://doi.org/10.4095/211549

Wemegah, D. D., Fiandaca, G., Auken, E., Menyeh, A., \& Danuor, S. K. (2017). Spectral Time-Domain Induced Polarisation and Magnetic Surveying-An Efficient Tool for Characterisation of Solid Waste Deposits in Developing Countries. EAGE Near Surface Geophysics, 15, 75-84.

Wemegah, D. D., Preko, K., Noye, R. M., Boadi, B., Menyeh, A., Danuor, S. K., \& Amenyoh, T. (2015). Geophysical Interpretation of Possible Gold Mineralization Zones in Kyerano, South-Western Ghana Using Aeromagnetic and Radiometric Datasets. Journal of Geoscience and Environment Protection, 3, 67-82.

https://doi.org/10.4236/gep.2015.34008

Wilford, J. R., Bierwirth, P. N., \& Craig, M. A. (1997). Application of Airborne Gamma-Ray Spectrometry in Soil Regolith Mapping and Applied Geomorphology. AGSO Journal of Australian Geology and Geophysics, 17, 201-216. 
Zhang, G., Lü, Q. T., Zhang, G. B., Lin, P. R., Jia, Z. Y., \& Suo, K. (2018). Joint Interpretation of Geological, Magnetic, AMT, and ERT Data for Mineral Exploration in the Northeast of Inner Mongolia, China. Pure and Applied Geophysics, 175, 989-1002.

https://doi.org/10.1007/s00024-017-1733-5 